\title{
THE ANALYSIS TOWARDS STATE APPARATUS COMMISSION ROLE IN ASN MANAGEMENT SYSTEM IN INDONESIA
}

\author{
Ajib Rakhmawanto \\ The Study and Personnel Research Center \\ National Sivil Service Agency of Indonesia \\ Email: ajib_mami@yahoo.com, ajib.bkn@gmail.com
}

\begin{abstract}
In administrating bureaurcy business process, professional state apparatus are needed. Law number 5 of 2014 about the state civil apparatus mentions management based on merit that supposed to be supervised by an independen institution: State Apparatuss Commision (KASN). This article aims to analyze the KASN, and identify its task, function, and responsibilities. The analysis showed that KASN was formed to create professional state apparatus and supervise the merit system based management. The function of KASN becomes ineffective considering there is NCSA, an establish body with a role to supervise the ASN management. KASN will cause an overlapping and conflict of interest between the two institutions.
\end{abstract}

Key words: state civil apparatus, merit system, bureaucracy.

\begin{abstract}
Abstrak
Dalam penyelenggaraan pemerintahan diperlukan dukungan pegawai ASN yang profesional. UU Nomor 5 Tahun 2014 Tentang ASN mengamanatkan adanya manajemen ASN berbasis merit yang diawasi lembaga independen KASN. Artikel ini bertujuan menganalisis pembentukan lembaga KASN serta mengidentifikasi peran pada tugas, fungsi, dan wewenangnya. Hasil analisis menunjukkan KASN dibentuk dengan tujuan untuk mewujudkan profesionalisme ASN dan mengawasi sistem merit manajemen ASN. Fungsi KASN menjadi tidak efektif mengingat sudah ada lembaga yang berperan menjalankan fungsi pengawasan manajemen ASN yaitu BKN. Adanya KASN dapat menyebabkan tumpang tindih dan benturan kepentingan pada kedua lembaga tersebut.
\end{abstract}

Kata kunci: aparatur sipil negara, sistem merit, birokrasi.

\section{Introduction}

The new phenomenon in government bureaucracy in Indonesia has uttered "Bureucracy reformation" in organization, business process, and human capital. Bureaucracy reformation is a basic alteration towards government organization system to create good governance. The implementation of good governance in reformation era is marked by the existence of institution in government which actively involves some components; state, private sector and the interacting community in doing their duties and functions. ${ }^{1}$ The implementation of e-govern-

Erna Hayati, “Mewujudkan Good Governance dalam Pengelolaan Pemerintahan Daerah Guna Memperkuat Integrasi Nasional", Education Porch Journal, Vol. 2 Number 2, of 2014, Banda Aceh: Faculty of Teacher Training ment is an important factor in creating good governance, so the relation which involves government, private, and society can be effectively and efficiently done which can increase the transparency and accountability in running the reign. ${ }^{2}$

Strategic alteration and new paradigm of government bureaucracy will directly affect to the personnel quality increasement of State Civil Apparatus (ASN). The lack of competence and low quality of human capital of ASN becomes the major problem which must be solved.

and Education Economy Serambi Mekkah University, page 7.

2 Marudur P Damanik, "Literasi Internet Masyarakat dalam Implementasi Pelayanan Publik E Government di Kabupaten Deli Serdang Provinsi Sumatera Utara", Widyariset Journal, Vol. 15 Number 1, April 2012, Jakarta: LIPI Press, page 68. 
As Azhar Kasim said, that competency and productivity of civil servants (PNS) are still low; in addition, they still have the rule driven, paternalistic, and unprofessional behavior. ${ }^{3}$ Human capital professionality training and development becomes one of the best efforts in facing and responding all of the challenges related to the strategic environment change. ${ }^{4}$ The merit system application in running the ASN management is a strategic action in increasing the ASN competence.

There are some problems related to the apparatus human capital in Indonesia which some of them are the high amount of civil servant (PNS), low quality, placement mistake, carrier obscurity, and competence discrepancy that they have with their responsibilities. ${ }^{5}$ Position filling is not matched with the merit principal that prioritizes the objectivity, competitiveness, and transparency. The research data result of Sjahrazas Masdar proves that in Surabaya, the regional secretary dismissal pattern is done with politic contents especially in perpetuating the position of regional head (Mayor) while in Situbondo Regency, if the regional secretary does not willing to accommodate what the Regional Head (Regent) want, there will be many efforts that will be done to dismiss him/ her from the position. ${ }^{6}$ It shows how weak the ASN personnel management in job promotion and mutation. Policy, implementation, and exist governmental institution supervision seems

3 Ratu Megalia, "Manajemen Peningkatan Kompetensi Aparatur: Studi tentang Implementasi Kebijakan Reformasi Sumber Daya Manusia pada Badan Pendidikan dan Pelatihan di Indonesia", Sosiohumanika Journal, Vol. 4 Number 2, of 2011, Bandung: Faculty of Social and Political Science Padjadjaran University, page 260.

4 Ellyta Yulliyanti, "Analisis Proses Rekrutmen dan Seleksi pada Kinerja Pegawai”, Business \& Burreaucracy Administration and Organization Science Journal, Volume 16 Number 3, September - December 2009, Jakarta: Faculty of Social and Political Science University of Indonesia, page 131.

5 Baharuddin dan Isra Djabbar, "Mengurai Merit Sistem Dalam Penempatan Jabatan Struktural", Public Administration Journal, Vol. X Number 1, June 2014, Makassar: PKP2A II LAN, page 12.

6 Rina Martini, "Politisasi Birokrasi di Indonesia", POLITIKA Political Science Journal, Vol. I, Number 1, April 2010, Semarang: Magister of Political Science Faculty of Social \& Political Science Diponegoro University, page 37. unable to overcome it, so independent ad hoc institution is needed.

The inception of the Law Number 5 of 2014 about State Civil Apparatus (ASN) is the basic plan to create ASN professionalism. Philosophical Law Number 5 of 2014 looks the importance of ASN management repairement as one of the important keys in running the bureaucracy reformation in ASN human capital. As it is mandated in Law Number 5 of 2014 Chapter VIII Section 51 says that ASN management is done based on merit system. Then, in Chapter VII Section 25 says that the government moneter running in policy, profession training, and ASN management needs the independent institution of State Apparatus Commission (KASN). The existence of KASN interesting seeing that there are 3 (institutions) that manage ASN, such as State Ministry for State Apparatus Reform (Kemen PAN-RB), National Civil Servie Agency (BKN), and Public Administration Institution (LAN).

This is the interesting main issues which will be analyzed in this article; first, why the KASN institution needs to be formed in ASN management system seeing that there have been three institutions which have done the role and what is the purpose?; second, how is the role of KASN and BKN in running its function seeing both institutions have the same role in controlling ASN? The analysis of this article is limited on the KASN formation analysis as well as KASN and $B K N$ role identification in controlling ASN. The purpose of the analyzing this article; first, analyzing various factors and purpose of KASN formation; second, KASN and BKN role identification in controlling ASN. The purpose of this article analysis is to get the meaning research and information about the purpose of KASN formation and the role of KASN and BKN in running the ASN controlling duty.

\section{Discussion}

ASN in Juridical Overview of Law Number 5 of 2014

Law Number 5 of 2014 is the law which regulates about State Civil Apparatus (ASN). The Law Number 5 of 2015 consists of XV Chap- 
ters and 141 Sections. Chapter I regulates the general stipulation; Chapter II regulates about basis, principle, basic value, ethic and behaviour code of ASN official; Chapter III regulates the gender, status, and position of the ASN official; Chapter IV regulates the function, duty, and role of ASN official; Chapter $V$ regulates about ASN function; Chapter VI regulates the right and obligation of ASN official; Chapter VII regulates the ASN official institutional organizer; Chapter VIII regulates the ASN management; Chapter IX regulates the JPT ASN filling; Chapter $\mathrm{X}$ regulates the position of ASN official as the state functionary; Chapter XI regulates the ASN organization; Chapter XII regulates the ASN information system; Chapter XIII regulates the ASN official quarrel settlement; Chapter XIV regulates the transfer stipulation; Chapter $\mathrm{XV}$ closing.

ASN as mentioned in Chapter I Section 1 Law Number 5 of 2014 is profession for Civil Servant (PNS) and governmental official with Work Agreement (PPPK) who works in government institution. PNS is Indonesian citizen (WNI) who fulfills the certain requirements, appointed to be permanent official of ASN to occupy the governmental position. PNS as the part of ASN is a profession, the consequence is increasing his/her ability to be professional in doing the responsibility. ${ }^{7}$ While PPPK is WNI who fulfills certain requirement, appointed based on the work agreement for certain pe-riod of time in doing the governmental duties. To support a clean and with authority government, all of state apparatus in doing their duties are obliged to do the general bases of a good governmental. ${ }^{8}$

ASN position consists of the Top Head Management/JPT, Administrative position, and Functional position. JPT is a group of top posi-

Mustaqiem, "Profesionalisme Pegawai Negeri Sipil dalam Peleyanan Publik", Civil Service Journal of Civil Servant (PNS) Policy and Management, Volume 4 Number 2, November 2010, Jakarta: Puskalitpeg BKN, page 10.

8 Tyas Dian Anggraeni, “Menciptakan Sistem Pelayanan Publik Yang Baik: Strategi Reformasi Birokrasi Dalam Pemberantasan Korupsi”, Rechtsviding Journal, Volume 3 Number 3, December 2014, Jakarta: Puslitbang SHN BPHN Kemenhukham, page 427 tion in governmental institution. Administrative position is a group of position which consists of the function and duties related to public service and governmental administration and development. Functional position is a group of position which contains function and duties related to the functional service based on certain competence and ability. The changed of ASN position without knowing Echelonisation term are JPT, Administrative position and functional position, therefore, Echelonisation has been changed to be position class, work load, and work achievement.

ASN appointment and position determining are done professionally, transparently, and independently based on merit system. Merit takes a role as the value or principle which conotated with fairness, justice, and reward in public employment based on achievement not by the political or discriminative or any other favoritism action. ${ }^{9}$ In NKRI context and in order to decrease politic cooptation, ASN position promotion system is opened for inter institution for the Central, Province, and Regency/City with the instrument assessment centre. ${ }^{10} \mathrm{JPT}$ is a new concept which those who are in Top Position in institution (Ministry/Institution/Regional) have strategic role to make sure the successful in reaching the institution and state purpose. ${ }^{11}$ The top position in ASN has function to lead and encourage ASN official by: first, the pioneering in competence about professional, analysis, policy recommendation, and management leadership; second, developing the cooperation with other institutions; and third, the good model in applying the ASN basic value and ethic code.

\section{Non Structural State Institution Formation Pattern}

\footnotetext{
Eko Prasojo and Laode Rudita, "Undang-Undang Aparatur Sipil Negara: Membangun Profesionalisme Aparatur Sipil Negara", Civil Service Journal of civil servant (PNS) policy and management, Volume 8 Number 1, June 2014, Jakarta: Puskalitpeg BKN, page 15.

10 Eko Prasojo, "Mengubah Kultur Birokrasi", Jawa Pos, July, $30^{\text {th }} 2012$.

11 Imam Alfie, "RUU Aparatur Sipil Negara: Revolusi Yang Dibutuhkan”, Kompas, September, $21^{\text {th }} 2012$.
} 
State institution according to AM Fatwa is the governmental institution in central which its function, duty, and authority are clearly settled by UUD, organization and institutional of this state can be seen if the meaning of state institution and moneter essence that is made into institution or organization to a state. ${ }^{12}$ The state institution should have a clear position, according to Philipus $M$. Hadjon position of the state institution; first, as a position of a state institution compared with other states' institution, second, the state institution position is based on its main function. ${ }^{13}$

Organization of institution in future should be filled with competence people as their job description to follow the trend and science development and Technology (IPTEK). That's why; SDM is very important and it has a strategic role as the actor maker which makes the other sources can be functioned in organization. ${ }^{14}$ Meanwhile, understanding for LNS is an institution which is formed because of urgency towards special duty which cannot placed into governmental institution (conventional) with certain uniqueness and urgent duty characteristic, unique and effectively integrated..$^{15}$ LNS is known as an independent state institution or support institution (state auxiliary state) which can be called as Council, Corporation or Institution, and can be called as State Commissions, can has a adhoc characteristic or which is called as duty unit or Committee.

The formation of the independent institutitons such as Commission is supported by the fact that bureaucracy in government environtment is valuated as something that no longer

12 A.M, Fatwa, "Tugas dan Fungsi MPR serta Hubungan Antar Lembaga Negara dalam Sistem Ketatanegaraan”, Majelis Journal, Volume 1, Number 1, August 2009, Jakarta: Setjen MPR RI, page 23.

13 Salmon E.M Erahua, "Kedudukan dan Kewenangan DPR dalam Sistem Ketatanegaraan Indonesia" Ius Quia lustum Law Journal, Volume 18 Number 4, October 2011, Yogyakarta: Law Faculty of Indonesia Islam University, page 591-592.

14 Zulpikar and Daniel Budi Santoso, "Analisis Komitmen Organisasional, Kepuasan Kerja, dan Kinerja Pegawai", Administration Science Journal, Volume III, Number 1, April 2011, Bandung : STIA LAN, page 82.

15 Hamdan Zoelva, 2010, Bunga Rampai Pemikiran Penataan Lembaga Non Struktural, Sekretariat Negara, Jakarta: Sekretariat Negara RI, page 5 can fulfill need of public service demand with a decreasing quality standar which, hopefully, can be more efficient and effective. The existence of LNS which manly functioned as the superintendant of the state institution's work is a form of disbelieve towards the previous exist institution. The LNS formation demand is also supported by the reality that during this time governmental bureaucracy cannot fulfill the public need demand for the good quality public service. According to Muladi, the reason of the Non Structural Institution (LNS) is to accommodate the participation of society as institutional in order to the velocity transition process in democracy. ${ }^{16}$

It is almost the same condition with KASN which is formed based on the weak ASN management running which does not apply the merit principle, the ASN low competence, ASN politic, and indicipline ASN etc. KASN as LNS has functioned to control the ASN management to run as the merit principle. KASN will bridge over the management running practice of ASN which is done by BKN or SDM Agency/Personnel Administration in Central institution and regional Personnel Admin-istration Agency in regional institution. The formation of KASN hopefully can keep the neutrality of ASN, control the ASN profession training, and report the ASN ma-nagement policy control and evaluation. In do-ing its duty, KASN can do the data and information investigation towards the running of the merit system in the ASN management and policy in Government institution.

\section{ASN Management System and KASN Role}

Profesional ASN management is the facility to do ASN personnel training. As written in the Chapter VII Section 25 Law Number 5 of 2014 that in doing the ASN personnel training, President delegates to Ministry, KASN, LAN, and $B K N$. Ministry relates to the general policy of ASN personnel utilization formulation authority. KASN relates to the ASN profession training

16 Muladi, “Penataan Lembaga Non-Struktural (LNS) Dalam Kerangka Reformasi Birokrasi Serta Upaya Formulasi Kebijakan Strategis Kelembagaan Negara", Negarawan Journal, Number 18, November 2010, Jakarta: Sekretariat Negara RI, page 21 
policy authority and its control in Institution and Agency. LAN relates to the state governmental administration development and research, education development and ASN training, and ASN Academy implementation. BKN relates to the ASN management training, organizing ASN candidate national selection, ASN work -assessment center training, ASN information system maintenance and development, and personnel Analysis functional education training.

The increasing new institution of KASN in ASN management will make the bureaucracy in ASN personnel system procedure to be longer. During this time for the exist institution, as it is roled by Ministry of PAN RB, BKN, LAN, BPKP, and Kemendagri, overlapping in managing SDM apparatus oftenly happens. In the Ministry of PAN there is of SDM Deputy, in LAN there is Apparatus Training and Education program Deputy, and in BKN ever there is PNS Development Deputy, which all of them have the same function as the SDM apparatus development. In the Ministry of PAN there is Accountability Deputy, in State Controller Agency (BPKP) there is Governmental Institution Controller Agency which all of them do the same work for government accountability. Related to policy in PAN Ministry there is Permenpan about Position Analysis, in BKN there is Perka about Position Analysis, and in Kemendagri there is also Permendagri about Position Analysis. The consequence, policies that are made by those institutions are usually out os sync which instead makes the institutions consumer confused.

This point shows that less good constitutional system when the ASN management runnings function is done by more than one state institution. This problem, sometimes, makes an unclearance in each institution role in taking policy, including the overlapping outhority which sometimes makes friction. This condition is estimated will be more complex if KASN not coordinates well with the institution which firstly exists. The main function of KASN is controlling the basic norm implementation, ASN behaviour code, and the merit system implementation in the ASN policy and management. It is similar to the BKN function in Supervision and Control Deputy which has duty to do the technical policy supervision and control arrangement, determining, and implementation in ASN personnel department.

Learning from Singapore in broad outline of the civil servant training process in Singapore is started from the identification of the personnel quality and quantity need by a group of policies to hire the civil servant candidates, identifying competence, ability and their talent. After it has been done, there will be recruitment for those candidates for being civil servant. Through precise need identification process, the right personel will be got to be civil servant. Those recruited personnel for the next will be kept and given development for their potential, talent, and their ability. The next step is by improving the quality, work performance and their competence through objective work assessment, measurable and systematic as well as by giving the proper appreciation.

The purpose of the civil servant training in Singapore is for creating an interesting civil servant value, maintaining and talent developing. The philosophies are: meristocracy; incurruptible; has the same opportunity; appreciating other people by maximilize their ability and potential, and understanding the strength and weakness; appreciating team work by working with various abilities and use team synergy; and giving appreciation for those who work hard and on time as the target, fair and rational distribution. In work measuring, assessment towards the potential is described as the highest determining approximation or the work level which finally ables to be done by a functionary before pension time.

In America, there is Civil Service Commission (CSC) to supervise the personnel running system by the arranged rules. CS is divided into 2 (two) such as Office of Personnel Management (OPM) and Merit System Protection Board (MSPB), the head of each is determined by President. MSPB has responsibility to protect the official right and importance, while OPM has responsibility for the official development running and facilitation, efficiency program and official productivity, state personnel regulation 
arrangement, and qualification for the official candidates, and affirmation action program. ${ }^{17}$ America in 1978 determined the Civil Service Reform Act (CSRA) to apply the merit system principles and prohibitions in official practice. The merit system in competence aspect and official professionalism, while the prohibition in discrimination aspect, using office facilities for public activities, and law violation, KKN.

Whereas, KASN in Indonesia is an independent LNS which is free from politic intervention to create professional and good-performance ASN official. The existence of the independent institution such as Commission does not exist in the branch area of legislative, executive or justice moneter, its position as the institution which helps the main institution, but sometimes this institution does a quasi independent. ${ }^{18}$ The purpose of KASN foundings are: first, assuring the merit system implementation in ASN policy and management; second, implementing the professional, high work performance, prosperous ASN, and function as NKRI adhesive; third, supporting the effective, efficient, and open governmental implementation and free from KKN practice; fourth, implementing ASN official which are neutral, who are not differenciate society that they serve based on ethnic, religion, race, and class; fifth, assuring the formed of ASN profesission which is honored by the official and society; and sixth, creating the dynamic and cultured ASN in work achievements.

The function, duty, and KASN institution authority as written in Chapter VII Section 30 Law Number 5 of 2014; first, the function of KASN in supervising the basic norm implementation, ASN ethic code and behavioural code, as well as the merit system implementation in ASN policy and management in government institu-

17 Janri Haposan UPS, "Perkembangan Sistem Kepegawaian Negara: Perspektif Komparatif Amerika dan Indonesia", Civil Service Journal of Civil Servant (PNS) Policy and Management. Vol. 1 Number 2, November 2007, Jakarta: Puskalitpeg BKN, page 58

18 Muranda Risang Ayu, "Kedudukan Komisi Independen sebagai State Auxiliary Institutions dan Relevansinya dalam Struktur Ketatanegaraan Indonesia", Constitution Journal, Volume I, Number 1, November 2009, Jakarta: Constitutional Court, page 57. tion. The values that are contained in basic norm become the held of the positive norms arrangement as unity. ${ }^{19}$ The function of KASN in supervising the value and basic norm of ASN means KASN has responsibility to monitor and straighten the value of Pancasila in the ASN personnels' spirit. In line with the ASN profession in applying the value of Pancasila, so an ASN official should have patriotism spirit such as bravery, unyielding, and sacrificing for the nation. The ASN personnel should also have the nasionalism in order to reach, keep, and serve the identity for nation and state.

Second, responsibility of KASN is keeping the neutrality of ASN personnel, doing supervision or ASN profession training, and reporting the ASN management policy implementation supervision and evaluation to President. In doing its duty, KASN can: do the data and information investigation towards the merit system implementation in the ASN policy and management; doing the supervision towards the ASN personnel function as the nation unifier implementation; accepting the report towards the basic norm, ethic code and behavioural code violation of the ASN personnel; doing the data and information investigation on the self initiative of ASN personnel towards the basic norm, ethic code, and behavioural code violation notion; and, doing the preventive effort towards the basic norm violation as well as the ASN personnel ethic code and behavioural code.

Third, authorities of KASN are: supervise each step of the JPT determining process starts from the institution committee recruitment formation, vacancy announcement, recruitment realization, candidate name enquiry, determining, until the Top Management Position; supervising and evaluating the basis, basic value, ethic code, and behavioural code of ASN personnel; asking information from the ASN personnel and society about the basic norm, ethic code and behavioural code violation report of ASN personnel in running the governmental duties;

19 Lukman Hakim, "Sengketa Kewenangan Kelembagaan Negara dan Penataannya Dalam Kerangka Sistem Hukum Nasional", Yustisia Law Journal, Volume 80, MayAugust 2010, Surakarta: Law Faculty of Solo State University, page 85. 
document investigating related to the basic norm, ethic code and behavioural code of ASN personnel; and, asking the clarification and/or the needed document form Government institution for report check on the basic norm, ethic code and behavioural code of ASN personnel.

Comparing with the Singapore, there are only two institutions which organize about civil servant management, such as Public Service Commission (PSC) which is an independent institution and Civil Service College (CSC). There are two kinds of Public Service Commission, such as: first, statutory functions such as determining and promoting civil servant who has top talent, doing the expeltion and discipline control, and approving the pension decision; and secon, non statutory functions such as doing PSC selection and organization, determinin and promoting the Chief Executive Officers PSC and doing the PSC scholarship administration. In the application of the civil servant discipline, there is a strict regulation. PSC gives authority to the Permanent Secretary to give discipline punishment for the civil servant until the Division I Grade III. The regulation in giving the discipline punishment is done by investigation, considering the normal justice, and giving the fair and consistent punishment.

Whereas, KASN has authority to do supervision on the Main and Madya JPT determining in Ministry, State Institution Secretary, Non Structural Institution, and Regional Institution which is done in open and competitive way in ASN circle by considering the competence, qualification, position, training and education program of government (Diklat), work track record, integrity, and other needed requirements as the law regulations. Besides, KASN also has an authority on the supervision towards the JPT Pratama determining which is done openly and competitively in ASN circle by considering the competence, qualification, position, education and training, work track record, integrity, and other needed requirements as the law regulations that is done openly and competitively in national level or Regency/City level in 1 (one) province.

\section{Closing}

KASN is LNS which is independently formed with reasons: first, the non existence of independent institution to create a merit system in the ASN policy and management; second, the minimum ASN competence which impacts to the government low work performance; third, the exists of KKN practice in government running; fourth, much bureaucracy politicism which causes the unneutral ASN personnel; and fifth, the unclear ASN profession which has main duties as public service.

The role of KASN in doing its function to keep the neutrality of ASN does the supervision for the ASN profession training and reports the ASN management policy implementation supervision and evaluation to President. The role of BKN on the Supervising and Controlling Deputy Work has function for the arrangging, determining, and technical policy supervision and control in personnel administration implementation. The function of KASN becomes less of the ideal/effective, seeing that there has been an institution which have role in running the ASN supervision function which is BKN. It will cause the interest overlapping and conflict on those two institutions.

\section{References}

Alfie, Imam. "RUU Aparatur Sipil Negara: Revolusi yang Dibutuhkan". Kompas, September, $21^{\text {st }} 2012$;

Anggraeni, Tyas D. "Menciptakan Sistem Pelayanan Publik yang Baik: Strategi Reformasi Birokrasi dalam Pemberantasan Korupsi. Jurnal Rechtsviding, Vol. 3 Number 3, December 2014. Jakarta: Puslitbang SHN BPHN Kementerian Hukum HAM;

Ayu, Muranda Risang. "Kedudukan Komisi Independen Sebagai State Auxiliary Institutions dan Relevansinya dalam Struktur Ketatanegaraan Indonesia". Jurnal Konstitusi, Vol. I, Number 1, November 2009. Jakarta: Makamah Konstitusi;

Damanik, Marudur P. "Literasi Internet Masyarakat dalam Implementasi Pelayanan Publik E-Government di Kabupaten Deli Serdang Provinsi Sumatera Utara", Widyariset Journal, Volume 15, Number 1, April 2012. Jakarta: LIPI Press; 
Djabbar, Isra dan Baharuddin. "Mengurai Merit Sistem dalam Penempatan Jabatan Struktural". Public Administration Journal, Vol X Nomor 1 June 2014. Makassar: PKP2A II LAN;

Erahua, Salmon E.M. "Kedudukan dan Kewenangan DPR dalam Sistem Ketatanegaraan Indonesia". Ius Quia lustum Law Jurnal, Vol. 18, Number 4, October 2011. Yogyakarta: Law Faculty of Indonesia Islam University;

Fatwa, A.M. "Tugas dan Fungsi MPR serta Hubungan Antar Lembaga Negara Dalam Sistem Ketatanegaraan". Majelis Journal, Vol. 1, Numberr 1, August 2009, Jakarta: Setjen MPR RI;

Hakim, Lukman. "Sengketa Kewenangan Kelembagaan Negara dan Penataannya dalam Kerangka Sistem Hukum Nasional". Jurnal Hukum Yustitia, Vol. 80, May-August 2010. Surakarta: Law Faculty of Indonesia Islam University;

Haposan, Janri UPS. "Perkembangan Sistem Kepegawaian Negara: Perspektif Komparatif Amerika dan Indonesia". Civil Service $\mathrm{C} i$ vil Service Journal of Civil Servant (PNS) Policy and Management, Vol. 1 Number 2, Nov 2007, Jakarta: Puskalitpeg BKN;

Hayati, Erna. "Mewujudkan Good Governance dalam Pengelolaan Pemerintahan Daerah Guna Memperkuat Integrasi Nasional". Education Porch Journal, Vol. 2, Number 2, September 2014. Banda Aceh: Faculty of Teacher Training and Education Economy Serambi Mekkah University;

Martini, Rina. "Politisasi Birokrasi Di Indonesia". POLITIKA Jurnal IImu Politik, Vol. I, Number 1, April 2010, Semarang: Political Science Magister of Social \& Political Sciences Faculty Diponegoro University;

Megalia, Ratu. "Manajemen Peningkatan Kompetensi Aparatur: Studi tentang Implementasi Kebijakan Reformasi Sumber Daya Manusia pada Badan Pendidikan dan Pelatihan di Indonesia". Sosiohumanika Journal, Vol. 4 Number 2 in 2011, Bandung: Faculty of Social \& Political Sciences Padjadjaran University;

Muladi. "Penataan Lembaga Non-Struktural (LNS) dalam Kerangka Reformasi Birokrasi serta Upaya Formulasi Kebijakan Strategis Kelembagaan Negara". Jurnal Negarawan Number 18, November 2010. Jakarta: Sekretariat Negara;
Mustaqiem. "Profesionalisme Pegawai Negeri Sipil dalam Peleyanan Publik". Civil Service Journal of Civil Servant (PNS) Policy And Management, Vol. 4, Number 2 November 2010. Jakarta: Puslitbang BKN;

Prasojo, Eko. "Mengubah Kultur Birokrasi". Jawa Pos, July, 30 ${ }^{\text {th }} 2012$;

dan Laode Rudita. "Undang-Undang Aparatur Sipil Negara: Membangun Profesionalisme Aparatur Sipil Negara", Civil Service Journal of Civil Servant (PNS) Policy and Management, Vol. 8 Number 1, June 2014, Jakarta: Puskalitpeg BKN;

Yulliyanti, Ellyta. "Analisis Proses Rekrutmen dan Seleksi pada Kinerja Pegawai". Business and Burreaucracy Journal of Administration and Organization Science, Vol. 16 Number 3, Sept-Dec 2009. Jakarta: Faculty of Social and Political Science University of Indonesia;

Zulpikar and Daniel B. Santoso. "Analisis Komitmen Organisasional, Kepuasan Kerja, dan Kinerja Pegawai". Administration Science Journal, Vol. III, Number 1, April 2011. Bandung: STIA LAN;

Zoelva, Hamdan. 2010. Bunga Rampai Pemikiran Penataan Lembaga Non Struktural. Jakarta: Sekretariat Negara RI. 